\title{
ANALIZA DIGITALNE PRISUTNOSTI NACIONALNIH FRANŠIZNIH UDRUGA
}

\author{
Dr. sc. Ljiljana Kukec, pred. \\ Sveučilište VERN' \\ e-mail: Ikukec@inet.hr
}

\begin{abstract}
Izv. prof. dr. sc. Aleksandar Erceg
Sveučilište Josipa Jurja Strossmayera u Osijeku, Ekonomski fakultet u Osijeku e-mail: aleksandar.erceg@efos.hr
\end{abstract}

Lorena Orašinović

Sveučilište Josipa Jurja Strossmayera u Osijeku, Ekonomski fakultet u Osijeku e-mail: lorena.orasinovic@efos.hr

\section{SAŽETAK}

Osnove franšiznog odnosa su prijenos know-howa, poslovnih tajni, specifičnih procedura $i$ mentorstva od strane davatelja franšize u zamjenu za financijsku kompenzaciju. Franšiza kao marketinški model za brzo geografsko širenje i umrežavanje nudi podjelu rizika, bolje i brže pozicioniranje i bolju konkurentnost. U tom složenom procesu značajnu ulogu imaju nacionalne franšizne udruge koje kroz svoje aktivnosti okupljaju glavne dionike franšiznog poslovnog modela, educiraju tržište i poduzetnike o franšizi, promoviraju i potiču razvoj franšiznog sektora. Cilj ovog istraživanja je dublji uvid u digitalne aktivnosti nacionalnih franšiznih udruga u svrhu ostvarenja njihovih ciljeva. Okosnica istraživanja su web stranice, ali i ostali kanali komunikacije povezani uz web stranice nacionalnih udruga. U okviru istraživanja za ove je potrebe korišten adaptirani model baziran na tri modela (Martinez \& Gauchi, 2010; Rao \& Frazer, 2005; Stefanović \& Stanković, 2014). Redizajnirani model evaluacije web stranica nacionalnih udruga fokusiran je na obim informacija koje se pružaju, njihovu korisnost, jednostavnost upotrebe stranice i promotivne aktivnosti na stranici. Značaj ovog istraživanja je dvojak. U prvom redu značaj je u adaptiranom modelu za istraživanje digitalne prisutnosti nacionalnih franšiznih udruga, dok je drugi značaj komparativna analiza njihova odnosa s nekim tržišnim indikatorima. Rezultati istraživanja daju doprinos teorijskom istraživanju franšiznog sektora u Europi i mogu biti okvir i osnova za daljnja istraživanja na nacionalnim razinama. Oni također daju dublje poimanje digitalne prisutnosti nacionalnih udruga u franšiznom poslovanju, što je dovelo do određenih zaključaka koji mogu poslužiti za bolje korištenje digitalnih alata za razvoj nacionalnih udruga i doprinos franšiznom poslovanju u svijetu. Konačni cilj istraživanja je doprinos iskorištavanju svih mogućnosti za promoviranje franšiznog poslovnog modela kao poluge za razvoj održivog poduzetništva i zapošljavanja.

Ključne riječi: franšize, franšizno poslovanje, franšizne udruge, Internet, digitalna prisutnost 


\section{UVOD}

Digitalizacija poslovanja postala je sve prisutnija i to posebice u proteklih 18 mjeseci tijekom trajanja pandemije bolesti COVID-19. U cilju zadržavanja i ostvarivanja konkurentnosti sve je više tvrtki pokrenulo ili pojačalo svoju digitalnu prisutnost bilo na mrežnim stranicama bilo na društvenim mrežama.

Franšizno poslovanje daje značajan poticaj međunarodnoj ekonomiji (Schwarzer, 2016) te je značajna globalna strategija rasta (Baena, 2018). S obzirom na to da popularnost franšiznog poslovnog modela i dalje raste, dolazi do stvaranja novih modela e-poslovanja, odnosno digitalne transformacije (Chen, 2019). Stoga i nacionalne udruge, u cilju praćenja i pružanja podrške svojim članovima, moraju prihvatiti nove tehnologije i prilagoditi svoje poslovanje rastućim potrebama dionika.

Cilj rada je uglavnom pružiti detaljno istraživanje o tome kako nacionalne i nadnacionalne franšizne udruge koriste Internet za promociju franšiznog poslovnog modela vanjskim dionicima te o tome što nude svojim članovima. Prvi dio rada daje pregled literature povezan s digitalnom prisutnošću franšize. Drugi dio predstavlja franšizne nacionalne i nadnacionalne udruge i njihovu povezanost s uspjehom franšiznog poslovnog modela. Treći dio rada bavi se web mjestima nacionalnih i nadnacionalnih franšiznih udruga i ispituje ih $s$ raspodjelom rezultata po varijabli i web mjestu. Na temelju rezultata istraživanja prezentirani su prijedlozi bolje upotrebe web stranica za sve dionike u cilju daljnje i bolje promocije franšiznog poslovnog modela. Završni dio predstavlja zaključak i predlaže daljnje istraživačke aktivnosti po pitanju digitalizacije poslovanja franšiznih udruga.

\section{FRANŠIZA I DIGITALNA PRISUTNOST}

Znanstvena istraživanja o međuodnosu franšiznog poslovnog modela i e-poslovanja (npr. e-marketinga, e-trgovine i dr.) i dalje su vrlo rijetka. No imajući u vidu pandemiju bolesti COVID-19, ista su počela dobivati na važnosti upravo zbog potrebe prilagođavanja poslovanja promjenama u okolini. Pénard \& Perrigot (2017) su ukazali na postojanje dviju grupa istraživanja ovog sve značajnijeg pitanja i to na (i) čimbenike koji omogućuju provedbu web mjesta davatelja franšize o e-trgovini i (ii) ispitivanje sadržaja web mjesta davatelja franšize. Plave i Amolosch (2000) su zaključili kako franšizni sistemi koriste e-prisustvo na četiri različita načina: (i) kao slobodno prisustvo, (ii) ovlaštenu i reguliranu prisutnost, (iii) koordiniranu prisutnost i (iv) potpunu zabranu. Rezultati pokazuju da se e-prisutnost kreće od potpune slobode u kreiranju web stranica do potpune zabrane e-prisustva u nekim franšiznim sistemima.

Cedrola i Memmo (2009) razmatrali su mogućnosti koje korištenje Interneta i e-prisustva pružaju franšiznom poslovanju (Slika 1). 
Slika 1. Mogućnosti Interneta za e-poslovanje

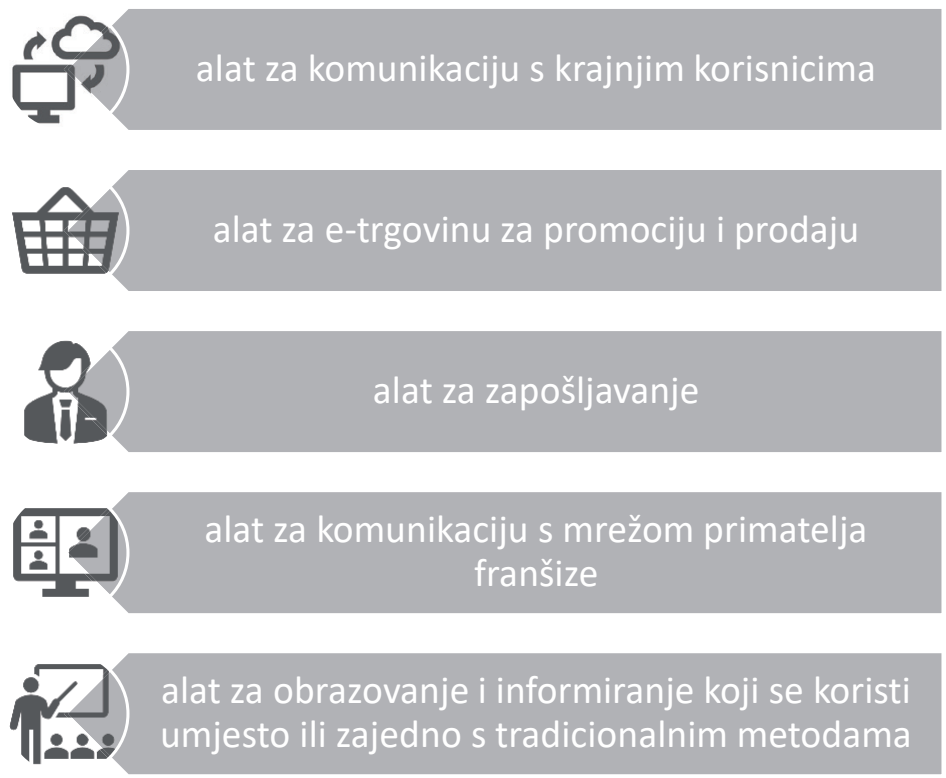

Izvor: Prilagođeno prema Cedrola i Memmo, 2009.

Pénard i Perrigot (2017) ističu kako brojni franšizni sistemi koriste svoje mrežne stranice, Facebook, Twitter, Linkedın ili druge društvene mreže za postizanje e-prisutnosti. Ovim alatima franšizni sistemi nastoje ostvariti komunikaciju sa svojim potencijalnim i/ili sadašnjim korisnicima radi pružanja informacija o svojim proizvodima i/ili uslugama. Dodatno, e-prisutnost se koristi radi prodaje i distribucije proizvoda kao dodatak svojim „stvarnim“ trgovinama.

Brojni autori (Galvan-Sanchez i sur., 2021; Kremez i sur., 2021; Pénard i Perrigot 2015; Plave \& Miller, 2001) ukazuju na to kako je odnos franšiznih sustava i e-prisutnosti pronašao svoje mjesto u akademskim disciplinama. Potrebno je istaknuti kako se e-prisustvo koristi za povećanje broja kupaca na širem geografskom području (Cliquet i Voropanova, 2016), dok franšizni sistem daje svojim primateljima zaštićeni teritorij (Dixon i Quinn, 2004.), što je suprotnost. lako e-prisustvo i e-trgovina omogućavaju učinkovitiju metodu distribucije (Madan i Yadav, 2018.), brojni franšizni sistemi imaju problem s korištenjem e-prisutnosti kako za svoje primatelje tako i za krajnje kupce (Kremez i sur., 2019).

Zbog svog propisanog sistema poslovanja, franšiza ima složeniji zadatak u koordiniranju e-prisutnosti i održavanju imidža brenda. Cedrola i Memmo (2009) kao glavnu komplikaciju ističu potrebu davatelja franšize da kreira i primijeni strategiju e-prisustva koja treba integrirati politiku sistema, distribuciju i strategiju marketinga, a istovremeno zadržati dobar odnos s primateljima. Nasuprot istraživanju koje su proveli Plave i Miller (2001), koji navode kako je e-prisustvo pogodno za franšizno poslovanje, Watson i sur. (2002) navode kako isto smanjuje potrebu za franšizom kao načinom zemljopisnog širenja. Dixon i Quin (2004) navode kako će e-trgovina kao dio e-prisustva spojiti tradicionalne i mrežne prodajne tehnike u cilju poboljšanja poslovanja. Pénard i Perrigot $(2015 ; 2017)$ proučavaju 
prednosti koje e-trgovina donosi prilikom nabave za franšizni sistem te ističu značajne koristi kako za davatelja tako i za primatelje franšize. lako ovaj spoj donosi brojne prednosti, Chen (2016) navodi kako je pomoć koju su imali davatelji franšize od vanjskih konzultanata u nekim slučajevima rezultirala sukobima između davatelja franšize i korisnika franšize budući da konzultanti nisu procijenili odnos u franšizi te su predložili pogrešnu strategiju e-trgovine.

Prethodno navedene studije pokazale su potrebu daljnjeg istraživanja odnosa e-prisustva i franšiznih sistema kao i boljeg razumijevanja logike iza izbora idealne metode za provedbu e-trgovine, posebno unutar priznatih franšiznih sustava, koji se često razvijaju na temelju tradicionalnih metoda marketinške razmjene.

\section{ULOGA FRANŠIZNIH UDRUGA U RAZVOJU FRANŠIZINGA}

Franšizno poslovanje razvijen je način poslovanja putem kojeg 15.350 europskih brendova širi svoje poslovanje i zapošljava više od 13 milijuna ljudi (Rose, 2021). Značajan je to doprinos bilo kojoj nacionalnoj ekonomiji, ali unatoč njegovoj snazi i taj model poslovanja, da bi se optimalno razvijao, treba svoje potporne institucije. Tu nacionalne franšizne udruge imaju značajno mjesto kao epicentar u čijoj orbiti se zapravo stvara svaki franšizni ekosustav. Te udruge su poslovna, sektorska udruženja koja se financiraju članarinama, potporama države te raznim aktivnostima. Fokus im je umrežavanje članova istih interesa u svrhu razvoja sektora, njihova boljeg tržišnog pozicioniranja i uzajamne pomoći kod internacionalizacije poslovanja, ali prvenstveno radi promocije i popularizacije samog sektora poslovanja, čime se stvara tržište za plasman franšiza njihovih članova (Young i Faulk, 2018).

Članovi takvih udruga mogu biti svi dionici franšiznog načina poslovanja. Osnivači su uglavnom sami davatelji franšiza, a često članovi mogu biti i njihovi primatelji te razni dobavljači, banke, odvjetnici i konzultanti. Veliki je udio domaćih franšiza u članstvu svake franšizne udruge iako i master primatelji stranih franšiza imaju u tom članstvu isti interes, a to je plasman svojih franšiza. Kako postojanje franšiznih udruga ima veliki značaj za razvoj tog sektora, tako i članstvo u istima sa sobom nosi niz koristi i često je presudno za sam plasman neke franšize. Brojne su koristi članstva u tim udrugama (Franchiseeurope. com, 2021).

Na prvom mjestu tu je kredibilitet same franšize u očima budućih kupaca s obzirom na to da svaka franšizna udruga ima visoka mjerila etičke i poslovne kvalitete za učlanjenje te se smatra da članstvom davatelj franšize ne prodaje, laički rečeno, „mačka u vreći“, već kvalitetnu franšizu iza koje stoji i sama udruga. Udruge članice Europske franšizne federacije (eng. European Franchise Federation - EFF) imaju poseban proces akreditacije za primanje u članstvo tijekom kojeg se provjerava franšiza te time samo članstvo daje neku vrstu jamstva. Zato članovi na svojim mrežnim stranicama koriste logotip udruge kao znak kvalitete u očima svojih investitora, a često i neku vrstu certifikata o članstvu.

Uvjeti za članstvo u takvim udrugama mogu varirati ovisno od udruge do udruge, ali uglavnom sadrže pregled franšiznog ugovora kako bi se ustanovilo zadovoljava li on etička i moralna načela franšiznog načina poslovanja, a za članove EFF-a provjerava se i usklađenje s Europskim etičkim kodeksom za franšizno poslovanje. Osim samog ugovora, često se 
moraju predstaviti i franšizni priručnik, način obuke i podrške te financijski podaci kako bi se vidjelo je li franšiza financijski izvediva i održiva (Bissitt, 2018).

Jedna od koristi je i bolja vidljivost. Cilj svakog davatelja franšize je prodaja franšize. Tu online prisutnost i što veća vidljivost osiguravaju generiranje interesa koji će voditi regrutiranju kandidata, kupaca franšize, a time i internacionalizaciji. Članstvo u udruzi doprinosi prepoznatljivosti brenda s obzirom na to da skoro sve udruge imaju na svojim web stranicama navedenu cijelu listu svojih članova s linkom na njihove web stranice. Sve to pomaže kod pozicioniranja brenda na tražilicama. U današnje vrijeme digitalna prisutnost udruga i njegove kvaliteta i iskoristivost glavni su uvjet za plasman franšiza. To je pogotovo važno u doba pandemije s obzirom na činjenicu da se nisu održavali sajmovi franšiza koji i dandanas najviše doprinose plasmanu franšiza. Digitalna prisutnost udruga bila je neizostavna tijekom pandemije, no ne treba zanemariti njezinu važnost i od ranije, a bit će sigurno presudna u budućnosti.

Kada govorimo o povećanju vidljivosti, govorimo i o predstavljanju članova na raznim konferencijama, webinarima, publikacijama, što su osnovne djelatnosti svake nacionalne franšizne udruge. Mnoge od njih dodjeljuju i godišnje franšizne nagrade svojim članovima u raznim kategorijama, što nominiranima i pobjednicima uvelike doprinosi u vidljivosti i prodaji franšize. Tu opet važnost ima digitalna prisutnost udruge, s obzirom na to da su se zadnjih godinu dana i te nagrade kao i edukacije odvijale online i one sigurno, s povratkom živih događanja, neće nestati, već će se koristiti neka hibridna forma s obzirom na njihov digitalni doseg koji je nerazmjerno veći od onoga uživo (Erceg, Kelić i Biloš, 2021).

Aktivnosti svake nacionalne franšizne udruge započinju organizacijom edukacija za stručno usavršavanje svojih članova, ali i edukacije tržišta. Vrlo često radi se o prijenosu znanja i iskustva između članova, no često se obrađuju i teme od zajedničkog interesa. I samo umrežavanje i razmjena raznih kontakata doprinose unapređenju poslovanja. Edukacije se odnose na organizaciju radionica, webinara, konferencija i kongresa, ali i na objavljivanje knjiga, publikacija, članaka i blogova (Kukec, Kukić i Ćorić. 2017).

Osnova članstva u nacionalnim franšiznim udrugama je umrežavanje članova, no s obzirom na to da te iste udruge traže mogućnosti članstva u nadnacionalnim organizacijama kako bi svojim članovima omogućile kontakte u inozemstvu, one se učlanjuju u razne federacije. Time zapravo franšizni lanci, članovi nacionalnih udruga imaju posredan pristup svojim kolegama u drugim zemljama, a udruge razmjeni znanja i iskustva s takvim udrugama globalno.

Može se zaključiti da je svrha postojanja franšiznih udruga da predstavljaju interese svojih članova, dionika franšiznog sektora poslovanja i da pomažu u izgradnji najbolje prakse i standarda za taj sektor poslovanja. S obzirom na to da mnoge zemlje još nemaju franšiznu legislativu niti zakon koji bi štitio primatelje franšize, samoregulacija sektora koja se odvija putem nacionalnih franšiznih udruga ili nadnacionalnih federacija čije su one članice, nameće se kao zaštita primatelja franšize i ima za svrhu potporu održivosti poslovanja svake franšize kroz nametanje etičkih normi koje pak jamče kvalitetu i održivost svake franšize članice nacionalnih udruga (Kukec, 2019).

Istraživanja su pokazala da iako u Europi djeluje nadnacionalni EFF, koji je nametnuo svojim članicama samoregulaciju kroz Europski etički kodeks za franšizno poslovanje (Europska komisija, 2016), to još uvijek nije dovoljno za adekvatnu zaštitu sektora. Naime, istraživa- 
nja pokazuju da samoregulacija u Europi ima doseg od samo $30 \%$ s obzirom na to da je u prosjeku samo toliko franšiznih brendova učlanjeno u nacionalne franšizne udruge, a time iste imaju utjecaj na samo jednu trećinu franšiznog sektora i ne mogu primjereno odigrati svoju ulogu. (Abell 2016). Ipak, ono na što imaju veliki utjecaj je tržište. Naime, svojom djelatnošću i aktivnostima udruge intenzivno rade na popularizaciji i promociji ovog načina poslovanja i time izravno doprinose rastu broja domaćih franšiza i njihove kvalitete.

\subsection{Internacionalni sustav nadnacionalnih franšiznih organizacija}

$\mathrm{Na}$ čelu svih nadnacionalnih i nacionalnih udruga u svijetu stoji Svjetsko franšizno vijeće (eng. World Franchise Council - WFC), koje trenutno broji četrdeset dvije zemlje članice uključujući i Hrvatsku. Njegovi su članovi nacionalne franšizne udruge, ali i nadnacionalne federacije (Slika 2).

\section{Slika 2. Mreža nadnacionalnih udruga u svijetu}

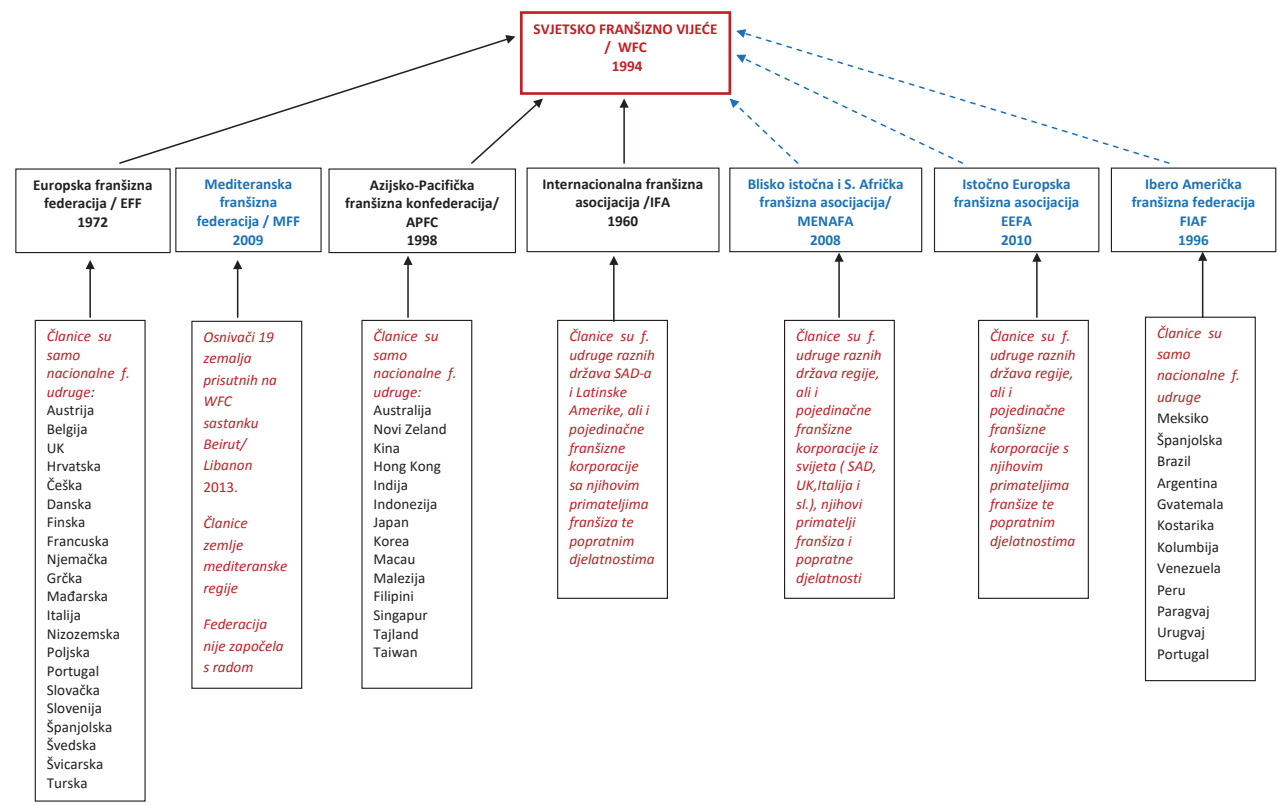

Izvor: Prilagođeno prema Kukec, Kukić i Ćorić, 2017.

Jedna od najstarijih franšiznih organizacija, čiji su članovi udruge, davatelji, primatelji franšiza, ali i dobavljači i razne strane organizacije je Međunarodna franšizna asocijacija (eng. International Franchise Association - IFA) iz SAD-a. Ima velik utjecaj s obzirom na iznimno razvijen franšizni sektor u tom dijelu svijeta i na veliki broj članova. IFA usko surađuje i s vladom i medijima te na taj način ima veliki utjecaj na javne politike. To je udruga koja predstavlja > 730.000 poduzeća koja stvaraju > 7,5 milijuna radnih mjesta u SAD-u, što predstavlja oko $3 \%$ američkog BDP-a (IFA, 2021). 
Azijsko-pacifička franšizna konfederacija (eng. Asia-Pacific Franchise Confederation-APFC) osnovana je 1988. godine kao nepolitička federacija nacionalnih franšiznih udruženja iz Azijsko-pacifičke regije s ciljem razmjene iskustava, informacija te znanja o franšiznom poslovanju, a najveća joj je vrijednost u tome što djeluje kao spona za internacionalizaciju kompanija. Članice ove udruge su: Australija, Kina, Hong Kong, Indija, Indonezija, Japan, Koreja, Macau, Malezija, Novi Zeland, Filipini, Singapur, Tajland, Tajvan, Turska i Ujedinjeni Arapski Emirati.

Bliskoistočno i sjeverno afričko franšizno udruženje (eng. Middle East and North Africa Franchise Association - MENAFA), osnovano 2008. godine, organizacija je čiji su članovi davatelji, primatelji franšize i popratna industrija. Nalazi se u regiji gdje je franšizni sektor prije pandemije rastao stopom od 27 \% godišnje te je ta organizacija glavno mjesto razmjene informacija, ponude i potražnje franšiza (MENAFA, 2021).

Sljedeća nezaobilazna i vrlo važna federacija je Ibero američka franšizna federacija (španj. Federación Ibero Americana de Franquicias - FIAF), osnovana 1996. godine. Ima 12 zemalja članica, a to su: Meksiko, Španjolska, Brazil, Argentina, Gvatemala, Kostarika, Kolumbija, Venezuela, Peru, Paragvaj, Urugvaj i Portugal. Osnovana je zbog činjenice da je to najveće govorno područje španjolskog i portugalskog jezika te osigurava internacionalizaciju tim tvrtkama prvenstveno $u$ ista govorna područja. Federacija se bavi edukacijom i dijeli najbolju praksu u franšiznom sektoru među svojim članovima, a i šire. Osim zajedničkog jezika, ove zemlje povezuju i slična povijest, običaji, religija i tradicija tako da je to vrlo plodno tlo za sve franšize koje se razvijaju u bilo kojoj od njih, što na franšiznom jeziku znači da je najmanji trošak i rizik za adaptaciju i pripremu sustava za internacionalizaciju. Ovo je ujedno i organizacija koja zastupa tržište sa 670 milijuna ljudi. (Elizarraras, 2016).

Panafrička federacija ima za cilj pomoći rastu franšiznog sektora poslovanja na afričkom kontinentu. lako trenutno vrlo malo zemalja u tom dijelu svijeta ima nacionalno udruženje ili planski razvoj franšiznog sektora, Panafrička federacija ima za cilj štititi, promovirati i razvijati etički franšizni poslovni model na afričkom kontinentu, a članice su joj nacionalne franšizne udruge.

Ipak, institucije koje imaju najviše stručnog i praktičnog znanja o franšiznom načinu poslovanja su same franšizne udruge. U pravilu su sastavljene od uspješnih poduzetnika - primatelja i davatelja franšize - te popratnih industrija. One olakšavaju međusobne kontakte između poduzeća te štite interese svojih članova. Glavna im je zadaća promocija koncepta franšiznog poslovnog modela kao poslovnog formata koji potiče razvoj poduzetništva, transfer znanja, tehnologije i vještina, što sve ima za pozitivnu posljedicu - zapošljavanje. Digitalna prisutnost nacionalnih franšiznih udruga presudna je u toj zadaći s obzirom na to da ima značajan utjecaj na internacionalizaciju poslovanja jer kreira znanja, vještine i umrežavanje, što direktno utječe na brzinu internacionalizacije franšiznih koncepata.

\section{METODOLOGIJA ISTRAŽIVANJA}

Esmeria i Seva (2017) ističu kako je prilikom istraživanja sadržaja web stranice potrebno da one imaju različite karakteristike i razloge kreiranja i korištenja. Razmatranje prethodnih istraživanja i alata za ocjenu stranica kojima se prezentiraju franšizni sistemi ukazalo je na to da se većina istraživanja temeljila na trima modelima, a to su: Rao i Frazer (2005), Martinez i Gauchi (2010) te Stefanović i Stanković (2014). Martinez i Gauchi koristili su 
model za mjerenje stupnja kvalitete franšiznih web stranica s gledišta krajnjeg korisnika. Rao i Frazer (2005) svoj su model koristili za ispitivanje web stranica kao komunikacijskog medija i to posebice za primatelje franšize i potencijalne primatelje franšize. Stefanović i Stanković (2014) koristili su model za ispitivanje kvalitete web stranica franšiznih sustava i to sa stajališta primatelja franšize te krajnjih kupaca proizvoda, odnosno korisnika usluga. Kombinaciju prethodna tri modela koristili su Erceg, Kelić i Biloš (2021) za ocjenjivanje kvalitete web stranica hrvatskih davatelja franšize.

Model koji se koristi u ovom radu naslanja se na revidirani model prethodnih modela koji su koristili Erceg, Kelić i Biloš (2021), pri čemu se ocjenjuju upotrebljivost web stranice i njen sadržaj te koristi koje su prilagođene franšiznim udrugama. Korišteni model ocjenjivanja sastoji se od dva skupa višeg ranga koji kombiniraju prethodne pristupe u ocjenjivanju web stranica franšiznog modela:

- A - Upotrebljivost web stranica (4 grupe s 22 predmeta),

- A1 - dizajn (8),

- A2 - navigacija (6),

- A3 - jezik (3),

- A4 - korisnička kontrola (5).

- B - Sadržaj web stranice (2 grupe s 18 predmeta),

- B1 - za članove udruge franšize (10),

- B2 - za druge dionike (8).

Svaki dio grupe mjeren je na dihotomnoj skali ( 1 - zadovoljava tvrdnju i 0 - ne zadovoljava tvrdnju). Ukupna ocjena revidiranog modela (Mfu) za ocjenjivanje stranica franšiznih udruga predstavlja zbroj upotrebljivosti web stranica (A) i sadržaja web stranica (B). Ukupna ocjena kreće se od 0 do 40, pri čemu viša ocjena ukazuje na veći broj zadovoljenih izjava (predmeta), odnosno web stranicu koja ima bolju izvedbu.

Zbog potencijalno subjektivne prirode proučavanih predmeta web stranica, svih troje istraživača je ocjenjivalo svaku web stranicu, nakon čega je napravljena grupna usporedba rezultata te donesen zaključak. Radi tumačenja rezultata, promatrana je srednja ocjena po predmetu proučavanja. Kao dodatna mjera za procjenu razine ispunjenih predmeta korišteno je ispunjavanje kriterija i to kao razina u odnosu na maksimalni rezultat (raspon od 0 do $100 \%)$.

\section{REZULTATI I RASPRAVA}

Revidirani model korišten je za procjenu uzorka od 43 web stranice nacionalnih franšiznih udruga te četiri web stranice nadnacionalnih franšiznih udruga, prvenstveno se fokusirajući na upotrebljivost i sadržaj web mjesta u smislu pruženih informacija, mogućnosti komunikacije i promotivnih aktivnosti. Prigodni uzorak kreiran je na osnovu popisa članova WFC-a (2021) i s upotrebom adresa web stranica koje su navedene na stranici WFC-a. Troje istraživača prvo je pojedinačno pregledalo i ocijenilo svih 47 web stranica u uzorku radi osiguravanja odgovarajuće razine objektivnosti prema 40 karakteristika. Kategorije koje su imale različite ocjene posebno su označene i o njima se raspravljalo na posebnim sesijama u cilju postizanja dogovora. Ocjenjivanje prema korištenom modelu provedeno 
je tijekom lipnja 2021., kao i nekoliko naknadnih sesija rasprava u vezi sa stavkama s različito ocijenjenim karakteristikama.

Na osnovi provedenog istraživanja jedna stranica ima najbolji rezultat (Južnoafrička Republika s ocjenom Mfu = 33, a nakon te stranice slijedi 17 web stranica čija je ukupna ocjena veća od 25 (Mfu > 25). Druga skupina od 17 stranica ostvarila je rezultat od 21 do 25 bodova, a preostalih 8 stranica je imalo ocjenu 20 i manje. Potrebno je napomenuti kako se iz daljnjeg proučavanja izuzelo mrežnu stranicu franšizne udruge Venezuele koja u promatranom vremenu nije radila.

Rezultati istraživanja nacionalnih udruga (Tablica 1.) pokazuju da su promatrane stranice imale prihvatljiv ishod dijela upotrebljivosti (Asuma) s prosječnom ocjenom 15,50 (sd = 2,521) od maksimalna 22, ispunjavajući $70 \%$ potencijala kriterija maksimalne ocjene. Većina proučavanih stranica dobila je dobre rezultate za dizajn $(A 1 m=6,48, s d=1,35$, $\max =8)$, kao i za navigaciju ( $\mathrm{A} 2 \mathrm{~m}=4,88, \mathrm{sd}=0,97, \max =6)$ te korisničku kontrolu ( $44 \mathrm{~m}$ $=2,88 \mathrm{sd}=0,80, \max =4)$, dok je jezik ostvario nižu ocjenu $(\mathrm{A} 3 \mathrm{~m}=1,26, \mathrm{sd}=, 50$, $\mathrm{max}=$ 2). $S$ druge strane, ocjene sadržaja stranica (B) bile su lošije u odnosu na upotrebljivost $s$ $\mathrm{Bm}=8,86(\mathrm{sd}=3,25)$ od potencijalnih 18 , što predstavlja samo $49 \%$ kriterija potencijalne maksimalne ocjene. Sadržaj za članove udruga je ostvario bolji rezultat $(B 1 \mathrm{~m}=6,05, \mathrm{sd}=$ $2,35, \max =10)$, dok je sadržaj za ostale dionike ostvario lošiji rezultat $(B 2 m=2,82$, sd = $1,41$, max $=7)$. Shodno prethodnim rezultatima, upotrebljivost promatranih nacionalnih stranica ima bolje rezultate u odnosu na ono što iste sadržavaju. Ukupna prosječna ocjena analiziranih stranica, Mfum, je 24,36 ( $\mathrm{sd}=4,84$, max = 33), što predstavlja 60 \% maksimalne ocjene stranica.

Tablica 1. Rezultati proučavanja mrežnih stranica nacionalnih udruga

\begin{tabular}{|c|c|c|c|c|c|c|c|c|c|}
\hline \multirow{2}{*}{$\begin{array}{l}\text { Nacionalne } \\
\text { udruge }\end{array}$} & \multicolumn{5}{|c|}{ Korisnost } & \multicolumn{3}{|c|}{ Sadržaj } & \multirow[b]{2}{*}{ Mfu } \\
\hline & $\mathrm{A} 1$ & A2 & A3 & A4 & A (suma) & B1 & B2 & B (suma) & \\
\hline Argentina & 7 & 6 & 1 & 2 & 16 & 8 & 4 & 12 & 28 \\
\hline Australija & 6 & 5 & 1 & 3 & 15 & 8 & 2 & 10 & 25 \\
\hline Belgija & 7 & 5 & 2 & 3 & 17 & 8 & 3 & 11 & 28 \\
\hline Bjelorusija & 8 & 5 & 1 & 3 & 17 & 7 & 2 & 9 & 26 \\
\hline Brazil & 5 & 5 & 1 & 3 & 14 & 4 & 1 & 5 & 19 \\
\hline Češka & 8 & 5 & 2 & 3 & 18 & 8 & 1 & 9 & 27 \\
\hline Danska & 6 & 4 & 1 & 1 & 12 & 6 & 0 & 6 & 18 \\
\hline Egipat & 6 & 3 & 1 & 3 & 13 & 4 & 2 & 6 & 19 \\
\hline Filipini & 8 & 6 & 1 & 3 & 18 & 9 & 5 & 14 & 32 \\
\hline Finska & 7 & 4 & 1 & 2 & 14 & 8 & 3 & 11 & 25 \\
\hline Francuska & 6 & 5 & 1 & 4 & 16 & 9 & 5 & 14 & 30 \\
\hline Grčka & 7 & 5 & 2 & 3 & 17 & 2 & 1 & 3 & 20 \\
\hline Gvatemala & 6 & 5 & 1 & 4 & 16 & 6 & 3 & 9 & 25 \\
\hline Hong Kong & 6 & 5 & 2 & 3 & 16 & 3 & 2 & 5 & 21 \\
\hline Hrvatska & 6 & 5 & 1 & 3 & 15 & 3 & 3 & 6 & 21 \\
\hline
\end{tabular}




\begin{tabular}{|c|c|c|c|c|c|c|c|c|c|}
\hline \multirow{2}{*}{$\begin{array}{l}\text { Nacionalne } \\
\text { udruge }\end{array}$} & \multicolumn{5}{|c|}{ Korisnost } & \multicolumn{3}{|c|}{ Sadržaj } & \multirow[b]{2}{*}{ Mfu } \\
\hline & A1 & $\mathrm{A} 2$ & A3 & A4 & A (suma) & B1 & B2 & B (suma) & \\
\hline Indija & 5 & 5 & 1 & 4 & 15 & 6 & 4 & 10 & 25 \\
\hline Indonezija & 2 & 1 & 0 & 1 & 4 & 2 & 1 & 3 & 7 \\
\hline Italija & 8 & 5 & 1 & 2 & 16 & 8 & 4 & 12 & 28 \\
\hline Japan & 5 & 4 & 2 & 1 & 12 & 8 & 2 & 10 & 22 \\
\hline Južna Afrika & 8 & 6 & 1 & 4 & 19 & 7 & 7 & 14 & 33 \\
\hline Kanada & 6 & 3 & 1 & 3 & 13 & 6 & 4 & 10 & 23 \\
\hline Kina & 4 & 5 & 2 & 3 & 14 & 1 & 1 & 2 & 16 \\
\hline Kolumbija & 6 & 5 & 1 & 2 & 14 & 8 & 4 & 12 & 26 \\
\hline Koreja & 5 & 4 & 1 & 3 & 13 & 8 & 2 & 10 & 23 \\
\hline Libanon & 8 & 5 & 1 & 4 & 18 & 7 & 4 & 11 & 29 \\
\hline Mađarska & 5 & 5 & 2 & 3 & 15 & 5 & 4 & 9 & 24 \\
\hline Malezija & 5 & 4 & 1 & 4 & 14 & 8 & 3 & 11 & 25 \\
\hline Meksiko & 8 & 5 & 1 & 3 & 17 & 6 & 3 & 9 & 26 \\
\hline Nizozemska & 8 & 5 & 1 & 3 & 17 & 8 & 2 & 10 & 27 \\
\hline Novi Zeland & 8 & 5 & 1 & 4 & 18 & 10 & 3 & 13 & 31 \\
\hline Poljska & 6 & 6 & 2 & 3 & 17 & 4 & 2 & 6 & 23 \\
\hline Portugal & 8 & 6 & 1 & 3 & 18 & 7 & 3 & 10 & 28 \\
\hline Rusija & 7 & 6 & 1 & 3 & 17 & 4 & 2 & 6 & 23 \\
\hline SAD & 8 & 5 & 1 & 3 & 17 & 7 & 2 & 9 & 26 \\
\hline Singapur & 6 & 5 & 1 & 3 & 15 & 5 & 3 & 8 & 23 \\
\hline Slovenija & 8 & 5 & 1 & 2 & 16 & 3 & 2 & 5 & 21 \\
\hline Španjolska & 6 & 6 & 1 & 3 & 16 & 4 & 3 & 7 & 23 \\
\hline Švedska & 7 & 5 & 2 & 3 & 17 & 9 & 3 & 12 & 29 \\
\hline Tajvan & 5 & 6 & 2 & 3 & 16 & 3 & 3 & 6 & 22 \\
\hline Turska & 7 & 5 & 2 & 4 & 18 & 8 & 3 & 11 & 29 \\
\hline UAE & 7 & 4 & 2 & 2 & 15 & 2 & 1 & 3 & 18 \\
\hline $\begin{array}{l}\text { Velika } \\
\text { Britanija }\end{array}$ & 7 & 6 & 1 & 2 & 16 & 7 & 6 & 13 & 29 \\
\hline Deskriptiva & $\mathrm{A} 1$ & $\mathrm{~A} 2$ & A3 & A4 & Asuma & B1 & B2 & Bsuma & Mfu \\
\hline $\begin{array}{l}\text { Aritmetička } \\
\text { sredina }\end{array}$ & 6,48 & 4,88 & 1,26 & 2,88 & 15,50 & 6,05 & 2,81 & 8,86 & 24,36 \\
\hline St. devijacija & 1,35 & 0,97 & 0,50 & 0,80 & 2,52 & 2,36 & 1,42 & 3,25 & 4,84 \\
\hline Minimum & 2 & 1 & 0 & 1 & 4 & 1 & 0 & 2 & 7 \\
\hline Maksimum & 8 & 6 & 2 & 4 & 19 & 10 & 7 & 14 & 33 \\
\hline $\begin{array}{l}\text { Ispunjenost } \\
\text { kriterija (\%) }\end{array}$ & & & & & $70,4 \%$ & & & $49 \%$ & $61,5 \%$ \\
\hline
\end{tabular}

Izvor: Autori 
Tablica 2. Rezultati proučavanja mrežnih stranica nadnacionalnih udruga

\begin{tabular}{|c|c|c|c|c|c|c|c|c|c|}
\hline \multirow{2}{*}{$\begin{array}{l}\text { Nadnacionalne } \\
\text { udruge }\end{array}$} & \multicolumn{5}{|c|}{ Korisnost } & \multicolumn{3}{|c|}{ Sadržaj } & \multirow[b]{2}{*}{ Mfu } \\
\hline & A1 & A2 & A3 & A4 & Asuma & B1 & B2 & Bsuma & \\
\hline APFC & 5 & 5 & 1 & 3 & 14 & 8 & 5 & 13 & 27 \\
\hline EFF & 8 & 6 & 1 & 3 & 18 & 6 & 2 & 8 & 26 \\
\hline FIAF & 6 & 4 & 2 & 3 & 15 & 3 & 0 & 3 & 18 \\
\hline $\begin{array}{l}\text { Pan African } \\
\text { Franchise } \\
\text { federation }\end{array}$ & 5 & 4 & 1 & 2 & 12 & 2 & 0 & 2 & 14 \\
\hline Deskriptiva & A1 & A2 & A3 & A4 & Asuma & B1 & B2 & Bsuma & Mfu \\
\hline $\begin{array}{l}\text { Aritmetička } \\
\text { sredina }\end{array}$ & 6,00 & 4,75 & 1,25 & 2,75 & 14,75 & 4,75 & 1,75 & 6,50 & 21,25 \\
\hline St. devijacija & 1,41 & 0,96 & 0,50 & 0,50 & 2,50 & 2,75 & 2,36 & 5,07 & 6,29 \\
\hline Minimum & 5 & 4 & 1 & 2 & 12 & 2 & 0 & 2 & 14 \\
\hline Maksimum & 8 & 6 & 2 & 3 & 18 & 8 & 5 & 13 & 27 \\
\hline $\begin{array}{l}\text { Ispunjenost } \\
\text { kriterija (\%) }\end{array}$ & & & & & $67 \%$ & & & $36 \%$ & $53 \%$ \\
\hline
\end{tabular}

Izvor: Autori

Rezultati istraživanja nadnacionalnih udruga (Tablica 2.) pokazuju da su promatrane stranice imale prihvatljiv ishod dijela upotrebljivosti (Asuma) s prosječnom ocjenom 14,75 $(s d=2,50)$ od maksimalno 22 , ispunjavajući $67 \%$ potencijala kriterija maksimalne ocjene. Većina proučavanih stranica dobila je dobre rezultate za dizajn $(A 1 m=6,00, s d=1,41$, $\max =8)$, kao i za navigaciju $(\mathrm{A} 2 \mathrm{~m}=4,75, \mathrm{sd}=0,96, \max =6)$ te korisničku kontrolu ( $\mathrm{A} 4 \mathrm{~m}$ $=2,75 \mathrm{sd}=0,50, \max =3)$, dok je jezik ostvario nižu ocjenu $(A 3 \mathrm{~m}=1,25, \mathrm{sd}=0,50, \mathrm{max}=$ 2). S druge strane, ocjene sadržaja stranica (B) bile su lošije u odnosu na upotrebljivost $s$ $\mathrm{Bm}=6,05$ (sd = 5,07) od potencijalnih 18, što predstavlja samo $36 \%$ kriterija potencijalne maksimalne ocjene. Sadržaj za članove udruga je ostvario bolji rezultat $(B 1 m=4,75$, sd $=2,75, \max =8)$, dok je sadržaj za ostale dionike ostvario lošiji rezultat $(B 2 m=1,75, \mathrm{sd}=$ $2,36, \max =5$ ). Shodno prethodnim rezultatima, upotrebljivost promatranih nadnacionalnih stranica ima bolje rezultate u odnosu na ono što iste sadržavaju. Ukupna prosječna ocjena analiziranih stranica, Mfum, je 21,25 ( $s d=6,29$ max = 27), što predstavlja 53\% maksimalne ocjene stranica.

Promatrane stranice nacionalnih i nadnacionalnih franšiznih udruga postigle su prosječne rezultate prema prilagođenom modelu procjene. Rezultati su pokazali kako upotrebljivost stranica ima veći utjecaj na ukupnu ocjenu, a da je ocjena sadržaja ukazala da postoji veliki prostor za poboljšanje stranica. Slične rezultate dobili su istraživanjem web stranica franšiznih sistema u Hrvatskoj Erceg, Kelić i Biloš (2021). Potreba za poboljšanjem u ovom istraživanju posebno je vidljiva u dijelu sadržaja za ostale dionike i to predstavlja najveću slabost promatranih stranica nacionalnih i nadnacionalnih franšiznih udruga. Obje grupe promatranja (upotrebljivost i sadržaj) web stranica zajednički pridonose onome što web stranica komunicira i onome što posjetitelj dobije te dodatno tim ciljevima koje u ovom slučaju franšizne udruge imaju. Stoga McClung i sur. (2012) ističu kako dobro dizajnirana i 
sadržajna stranica u franšiznom poslovnom modelu može poslužiti kao odličan promotivni alat u marketinškom pristupu.

Prethodna istraživanja (Rao i Frazer, 2005; Martinez i Gauchi, 2010; Stefanović i Stanković, 2014) pokazala su slične rezultate. Upotreba digitalnih tehnologija i mogućnosti koje Internet pruža više su usmjerene na pružanje informacija krajnjim korisnicima (u ovom slučaju članovima udruga) nego potencijalnim korisnicima i ostalim dionicima.

Modificirani način ocjenjivanja omogućio je bolji pristup razumijevanju web stranica nacionalnih udruga no postoji nekoliko ograničenja upotrebe ovog koncepta. Na upotrebljivost web stranica značajan utjecaj ima i korišteni način kreiranja stranice jer na tom području može doći do značajnog napretka u kratkom vremenskom razdoblju. Dodatno ograničenje je i subjektivnost ocjenjivanja, što u konačnici može rezultirati potrebom za većim brojem istraživača u samom postupku ocjenjivanja. Stoga bi se daljnji istraživački napori trebali usmjeriti na otklanjanje tih ograničenja te predlaganje boljih i strožih rješenja za testiranje web stranica.

\section{ZAKLJUČAK}

Sa sve većom važnosti digitalizacije, a u svrhu veće efikasnosti, sve više nacionalnih franšiznih udruga pojačava svoju digitalnu prisutnost s ciljem promocije i popularizacije franšiznog sektora i svojih članova. Članstvo u istima sa sobom nosi niz koristi i često je presudno za sam plasman franšiza putem digitalne prisutnost udruga, čime se osigurava generiranje kupaca franšize i internacionalizacija.

Cilj rada bio je detaljno istraživanje o tome kako nacionalne i nadnacionalne franšizne udruge koriste Internet za svoju svrhu i aktivnosti prema svojim članovima i vanjskim dionicima. Istraživanje je dovelo do zaključaka koji mogu poslužiti za bolje korištenje digitalnih alata, ali i za benchmarking u svrhu poboljšanja digitalne prisutnosti udruga i njihove efikasnosti.

Od 43 nacionalne udruge i četiri nadnacionalne, najbolji rezultat u svim kategorijama postigla je stranica udruge iz Južnoafričke Republike s velikim odmakom od drugih udruga. Ona može poslužiti kao benchmarking za digitalnu prisutnosti za sve ostale.

Kada se zbroji još 17 udruga koje imaju vrlo visoke ocjene (iznad 25), onda možemo reći da 42 \% ispitanih udruga ima vrlo dobre rezultate, koji su opet puno bolji u dijelu upotrebljivosti stranica nego u dijelu njihovog sadržaja. Ukupna prosječna ocjena analiziranih stranica predstavlja samo 60 \% maksimalne ocjene, što pokazuje veliki prostor za napredak.

Kod nacionalnih udruga istraživanje je također pokazalo da postoji veliki prostor za poboljšanje u okviru sadržaja za nečlanove i ostale dionike, što bi u konačnici doprinijelo povećanju broja članova nacionalnih udruga te osiguralo njezin veći doseg u franšizni sektor, s obzirom na to da je on sada samo $30 \%$. Analiza nadnacionalnih udruga pokazala je da su njihove ocjene nešto bolje u okviru upotrebljivosti stranica od stranica nacionalnih udruga, ali dosta lošije u okviru sadržaja. Razlog tome može se tražiti u činjenici da je svrha njihova postojanja više političko-lobistička s ciljem umrežavanja nego komercijalna kao što je to slučaj kod nacionalnih udruga. 
Provedeno istraživanje ukazuje na veliki značaj koji Internet i e-prisustvo imaju za franšizno poslovanje i franšizne udruge. Daljnjim razvojem tehnologije rast će i značaj e-poslovanja. Stoga je iznimno važno da nacionalne i nadnacionalne franšizne udruge povećaju upotrebu ovih alata u promoviranju svojih aktivnosti ne samo prema svojim članovima (davateljima i primateljima franšize) nego i ostalim dionicima, od kojih će neki možda postati potencijalni davatelji ili primatelji franšize. Ovim će udruge doći do svojih novih članova, a istovremeno će se i franšizni poslovni model nastaviti razvijati te doprinositi nacionalnim ekonomijama.

Činjenica da 42 \% stranica ima visoku ocjenu otvara mogućnost nekih budućih istraživanja, kako kvantitativnih tako i kvalitativnih, kako bi se dobio uvid u točna područja sadržaja ili upotrebljivosti, koja ostalih 58 \% udruga može primijeniti za svoju bolju digitalnu prisutnost i poslovnu efikasnost. Isto tako jedno od mogućih budućih istraživanja moglo bi biti komparativno istraživanje digitalne prisutnosti članova pojedinih nacionalnih udruga kako bi se mogli usporediti rezultati s rezultatima njihovih udruga s obzirom na to da su im ciljevi zajednički, a to je jačanje sektora i promocija i popularizacija istoga u svrhu komercijalizacije franšiza. 


\title{
ANALYSIS OF DIGITAL PRESENCE OF NATIONAL FRANCHISE ASSOCIATIONS
}

\author{
Ljiljana Kukec, PhD \\ VERN' University \\ e-mail: Ikukec@inet.hr \\ Assoc. prof. Aleksandar Erceg, PhD \\ Josip Juraj Strossmayer University of Osijek, Faculty of Economics in Osijek \\ e-mail: aleksandar.erceg@efos.hr \\ Lorena Orašinović \\ Josip Juraj Strossmayer University of Osijek, Faculty of Economics in Osijek \\ e-mail: lorena.orasinovic@efos.hr
}

\section{ABSTRACT}

The basics of a franchise relationship are transferring knowledge, trade secrets, specific procedures, and mentoring by the franchisor in exchange for financial compensation. The franchise as a marketing model for rapid geographic expansion and networking offers risk sharing, better and faster positioning, as well as better competitiveness. National franchise associations have a significant role in this complex process. Through their activities, they bring together the main stakeholders of the franchise business model, educate the market and entrepreneurs about franchising, promote and encourage the development of the franchise sector. This research aims to provide a deeper insight into the digital activities of national franchise associations with the aim of achieving their goals. The backbone of the research is websites and other communication channels connected to the websites of national associations. An adapted model based on three models was used for these needs (Rao and Frazer, 2005; Martinez and Gauchi, 2010; Stefanović and Stanković, 2014). The redesigned model of evaluation of the national association's website is focused on the scope of information that provides their usefulness, user-friendliness of the site, and promotional activities on the site. The significance of this research is twofold. It primarily lies in the adapted model for researching the digital presence of national franchise associations. At the same time, the second importance is thatof a comparative analysis of their relationship with some market indicators. The research results contribute to the theoretical research of the franchise sector in Europe and can be a framework and basis for further research at national levels. They also provide a deeper understanding of the digital presence of national associations in franchising, which has led to certain conclusions that may serve for a better use of digital tools for developing national associations and contribute to franchising in the world. The research aims to use all the opportunities to promote the franchise business model as a lever for sustainable entrepreneurship and employment development.

Keywords: franchises, franchise business, franchise associations, the Internet, digital presence 


\section{LITERATURA}

1. Abell, M. (2016). Legal perspective of regulatory framework and challenges for franchising in EU. Preuzeto s www.europarl.europa.eu/committees/en/events-workshops.html.

2. Baena, V. (2018). International franchise presence and intensity level: Profile of franchisors operating abroad. Management Research Review, 41(2), 202-224. doi:10.1108/MRR-01-20170011.

3. Bissitt, J. (2018). Why join a franchise association. Quality franchise association. Preuzeto $s$ https://www.franchise-association.org.uk/why-join-a-franchise-association/.

4. Bruce A, Seaman and Deniss R. Young Cedrola, E. i Memmo, S. (2009). Internet for Franchising: Current Use and Areas of Improvement-Results of an Empirical Research. Journal of Euromarketing, 18(1), 5-21.

5. Chen, Y-S. (2016). E-commerce in international franchising. Encyclopedia of E-Commerce Development, Implementation, and Management. IGI Global, 578-590.

6. Chen, Y-S. (2019). E-Entrepreneurship and Innovation in Franchising. International Journal of E-Entrepreneurship and Innovation, 9 (1), 1-2. doi:10.4018/IJEEI.2019010101.

7. Cliquet, G. i Voropanova, E. (2016). E-commerce and encroachment: evidence from French franchise networks. Journal of Marketing Channels, 23 (3), 114-128. doi: 10.1080/ 1046669X.2016.1186471.

8. Dixon, H. i Quinn, B. (2004). Franchising and the internet: an exploratory study of franchisor web sites. Internet Research, 14 (4), 311-322. doi: 10.1108/10662240410555324.

9. Elizarraras, D. (2016). FIAF's goals and future activities. Prezentacija na sastanku WFC, Bologna, 30.04.2016.

10. Erceg, I. Kelić, A. i Biloš (2021). Evaluation of franchise system websites: the evidence from Croatia. Engineering management in production and services, 13 (1), 27-38. doi: 10.2478/emj2021-0002.

11. Esmeria, G. J. i Seva, R. R. (2017). Web usability: a literature review. In DLSU Research Congress 2017, De La Salle University, Manila, Philippines.

12. Europska komisija (2016). EFF European Code of Ethics for Franchising. Preuzeto $s$ https:// ec.europa.eu/digital-single-market/en/content/eff-european-code-ethics-franchising.

13. Galván-Sánchez, I., Fernández-Monroy, M., Domínguez-Falcón, C. and Galván-Ríos, E. (2021). Exploring Digital Communication in Franchising in Spain: A Website Review, Economics, Business and Organization Research, 3(1), pp. 1-26.

14. International Franchise Association (2021). Economic outlook for franchising. Preuzeto $s$ https://www.franchise.org/sites/default/files/2021-02/Economic\%200utlook\%202021_ web2.pdf.

15. Kremez, Z., Frazer, L. i Thaicon, P. (2019). The effects of e-commerce on franchising: Practical implications and models. Australasian Marketing Journal, 27 (3), 158-168. doi: 10.1016/j. ausmj.2019.04.002.

16. Kremez, Z., Frazer, L., Weaven, S. i Quach, S. (2021). Ecommerce structures for retail and service franchises: commerce implementation in mature franchise systems. Asia Pacific Journal of Marketing and Logistics, 33 (6), 1292-1308. doi: 10.1108/APJML-11-2018-0461.

17. Kukec, Lj. (2019). Franšizni potencijal malih poduzeća, doktorska disertacija, Ekonomski fakultet Osijek. 
18. Kukec, Lj., Kukić, K., i Ćorić, G. (2017). Uloga franšiznih udruga u razvoju franšiznog sektora, usporedba europskih iskustava. Obrazovanje za poduzetništvo - E4E : znanstveno stručni časopis o obrazovanju za poduzetništvo, 7 (1), 143-160.

19. Madan, K. i Yadav, R. (2018). Understanding and predicting antecedents of mobile shopping adoption. Asia Pacific Journal of Marketing and Logistics, 30(1), 139-162. doi:10.1108/apjml02-2017-0023.

20. McClung, S., Eveland, V., Sweeney, D. i James, J. D. (2012). Role of the Internet site in the promotion management of sports teams and franchise brands. Journal of Promotion Management, 18(2), 169-188.

21. Middle East and North Africa franchise association (2021). About us. Preuzeto s http://www. menafa.com/.

22. Pénard, T. i Perrigot, R. (2015). Search Online - Purchase Online in Franchising: An Empirical Analysis of Franchisor Website Functionality, Economics Working Paper Archive (University of Rennes 1 \& University of Caen) 201517, Center for Research in Economics and Management (CREM), University of Rennes 1, University of Caen and CNRS.

23. Pénard, T. i Perrigot, R. (2017). Online search - Online purchase in franchising: An empirical analysis of franchisor website functionality. Journal of Retailing and Consumer Services, 39, 164-172. doi: 10.1016/j.jretconser.2017.08.003.

24. Plave, L. J. i Amolsch, R. B. (2000). How to implement Dot.com franchising solutions: Two aspects of a multifaceted issue. Franchising World, 32(5), 17-19.

25. Plave, L. J. i Miller, K.M. (2001). International franchising \& e-commerce: adapting franchise systems to the global electronic marketplace. International Journal of Franchising and Distribution Law, 3 (4), 259-313.

26. Rao, S. i Frazer, L. (2005). The use of Internet-based Technologies in Australian Franchise Systems: A Preliminary Study. Journal of Internet Business, 2(2), 1-19.

27. Rose F. (2021). The Franchise center UK. Prezentacija na webinaru: Woman in franchising, Dubai business women council 3/2021.

28. Schwarzer, P. (2016). World Franchise Council - Survey on the Global Economic Impact of Franchising. Arlington: FranData.

29. Stefanović, S. i Stanković, M. (2014). The Role of ICT and the Internet in the Development of Franchise Systems. Economic Themes, 52(4), 409-435.

30. Wallace. M. (2019). The benefits of joining the franchise association, Franchise Europe. Preuzeto s https://www.franchiseeurope.com/information/the-benefits-of-joining-a-franchiseassociation.

31. Watson, A., Kirby, D. A., i Egan, J. (2002). Franchising, retailing and the development of e-commerce. International Journal of Retail \& Distribution Management, 30(5), 228-237. doi: 10.1108/09590550210426390.

32. Young, D. R. i Faulk, I. (2018). Handbook of research on nonprofit economics and management. Franchises and federations: the economics of multi-site nonprofit organizations, 300-322. 